Pamiętnik Literacki 2015, 1, s. 5-22
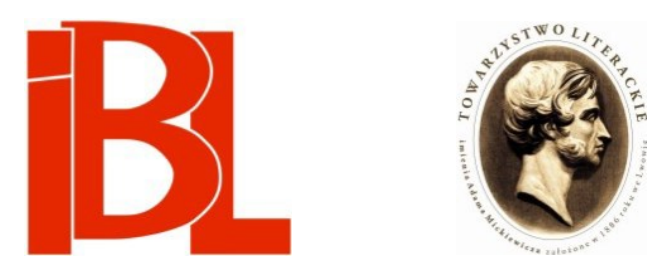

\title{
Cosmopoiesis Jana Kochanowskiego
}

\author{
Jacek Sokolski
}




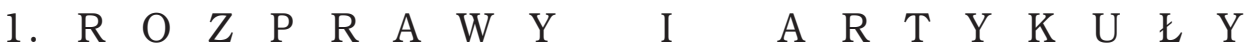

Pamiętnik Literacki CVI, 2015, z. 1, PL ISSN 0031-0514

JACEK SOKOLSKI Uniwersytet Wrocławski

\section{COSMOPOIESIS JANA KOCHANOWSKIEGO}

Przed pół wiekiem Northrop Frye pisał: „Świat literatury jest światem, gdzie nie ma

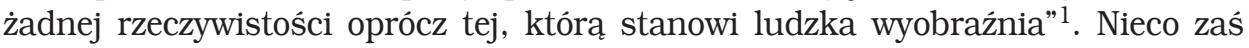
dalej dodawał:

Literatura przemawia językiem wyobraźni, a studium literatury zakłada ćwiczenie i doskonalenie wyobraźni. Wyobraźnią jednak posługujemy się nieustannie: pojawia się on w każdej naszej rozmowie i w praktycznym życiu; produkuje nawet sny, kiedy śpimy. W rezultacie mamy jedynie wybór między źle wyćwiczoną wyobraźnią a tą wyćwiczoną dobrze, niezależnie od tego, czy kiedykolwiek przeczytaliśmy jakiś wiersz, czy też nie².

Obcowanie $z$ dawna poezją wymaga od nas, byśmy naszą imaginację poddali bardzo szczególnemu rodzajowi treningu. Wszelka twórczość zmierza bowiem przede wszystkim do systematycznego ujmowania ludzkich doświadczeń i przemyśleń w symboliczne formy - według zasad, które nie są ani odwieczne, ani niezmienne. Część z nich ma, oczywiście, charakter jednostkowy, indywidualny, ściśle związany z osobowością konkretnego twórcy, co w skrajnych przypadkach naraża go na całkowite niezrozumienie zarówno przez współczesnych, jak i przez potomnych, inne odwołują się do pewnego szerszego, historycznie ukształtowanego kodu, którego przestrzeganie ułatwiało pierwotnie pisarzom i artystom proces komunikowania się $z$ otoczeniem (lub przynajmniej z jego częścią), dzisiaj jednak sprawia niekiedy, że wspomniani tutaj potomni zaczynają mieć różne interpretacyjne problemy. $\mathrm{Ba}$, zdarza się często, że problemów tych w ogóle nie dostrzegają, przywykli bowiem do posługiwania się w swoich dociekaniach kwestionariuszami, które od dawna nie zawieraja już właściwych pytań, ich zaś wyobraźnia jest w pewnym sensie „niekompatybilna” z egzotycznym światem przedstawień utrwalonych w dziełach dawnych pisarzy. Niniejszy artykuł traktuje, oczywiście, przede wszystkim o twórczości największego poety dawnej Polski, przy okazji jednak celem miało być tu także ukazanie rozmaitych pożytków poznawczych płynących właśnie z systematycznego ćwiczenia wyobraźni.

W roku 1561 (lub najpóźniej w pierwszej połowie roku następnego) ${ }^{3}$ krakowska

N. F ry e, The Educated Imagination. Bloomington, Ind., 1964, s. 96.

Ibidem, s. 134-135.

O dacie wydania poematu pisała P. Bu chwald - Pelc ow a (Dawne wydania dziet Jana Kochanowskiego. Warszawa 1993, s. 25). 
oficynę Matysa Wirzbięty opuściła Zuzanna, niewielki poemacik Jana Kochanowskiego, jeden $z$ pierwszych drukowanych tekstów początkującego wówczas poety, z dodaną na końcu sławną pieśnią, zaczynającą się od słów „Czego chcesz od nas, Panie, za twe hojne dary”. Sama Zuzanna jest dziełkiem, któremu trudno odmówić, oczywiście, pewnych literackich walorów, dodatek przyćmił wszakże jej sławę i po dziś dzień uchodzi za jedno $\mathrm{z}$ arcydzieł dawnej polskiej poezji. W swoim czasie Wiktor Weintraub nazwał go nawet „manifestem renesansowym”, słusznie chyba przyjmując, że znalazła w nim swoje wyraźne odzwierciedlenie nowa postawa poety wobec świata, charakterystyczna dla epoki, w której utwór powstał. Weintraub pisał zatem:

Poemat to religijny, napisany ku chwale Boga. Jednocześnie jednak opiewa on świat, wspaniałość, piękno i harmonię tego świata. W porównaniu z Bogiem ziemię można nazwać „niską”, tym niemniej jej doskonałość jest odbiciem boskiej wielkości i świadectwem boskich dobrodziejstw. W wierszu Kochanowskiego Bóg wielbiony jest poprzez to, co stworzył, ale cały utwór przepojony jest głębokim optymi$\mathrm{zmem}^{5}$.

Przytoczony fragment utrzymany jest w tradycyjnym, zdecydowanie burckhardtowskim duchu: hymn miałby w tym ujęciu stanowić kolejną egzemplifikację owego renesansowego „odkrycia świata”, o którym 100 lat wcześniej pisał szwajcarski historyk. Dzisiaj zdajemy sobie dobrze sprawę z różnych wpisanych w tę koncepcję renesansu uproszczeń i dlatego nie będę tutaj z nią dyskutował. Zrobili to już inni. $Z$ naszego punktu widzenia ważniejsze jest coś innego. W świetle całego dalszego wywodu Weintrauba pieśn Kochanowskiego okazuje się bowiem tylko manifestacją pewnej postawy, występującej również w niektórych innych wczesnych utworach poety, ale nie manifestem. Żeby mogła nim być, musiałaby zawierać jakiś program działań. Za manifest poetycki można w tym sensie uznać np. Muzę, ale nie pieśń Czego chcesz od nas, Panie... Utwór ten jest tylko punktem wyjścia, opisem początku drogi, którą miał w przyszłości podążyć poeta.

Nie wiadomo zresztą, czy już w latach sześćdziesiątych przewidywał, dokąd go ta droga zaprowadzi. Utrwalone w hymnie pierwsze na niej kroki wiodą od contemplatio, poprzez admiratio, do laudatio Creatoris. Trudno jednak oprzeć się przy okazji wrażeniu, iż przedmiotem największego zachwytu jest dla Kochanowskiego nie tyle sam świat rzeczy stworzonych, jego piękno i ład, ile raczej tajemnicza siła, która powołała go do istnienia. Bóg, na co już wielokrotnie zwracano uwagę, występuje tutaj jako Summus Artifex, przypominający bardziej owego pojawiającego się w Timajosie Platońskiego demiurga niż Stwórcę znanego z dzieł żydowskich i chrześcijańskich teologów. Jako taki może on, a nawet powinien, stać się również obiektem imitatio. Kochanowski nigdzie czegoś podobnego nie napisał, wnikliwe spojrzenie na jego dalszą drogę twórczą, zwłaszcza zaś na jej późny, czarnoleski etap, kiedy to, jak wszystko wskazuje, swojemu dziełu postanowił nadać ostateczny kształt, skłania jednak do postawienia tezy, iż tak właśnie uważał. Domysł ten znajduje potwierdzenie także w tym, co wiemy na temat pewnych szerszych zjawisk

4 W. W e in tra u b, Manifest renesansowy. W: Rzecz czarnoleska. Kraków 1977.

5 Ibidem, s. 289. Nie bardzo jednak rozumiem, dlaczego drugi człon ostatniego zdania został poprzedzony spójnikiem „ale”. 
charakterystycznych dla kultury renesansu, w której przecież polski poeta na różne sposoby uczestniczył.

Niemal jednocześnie z Zuzanna ukazało się, tyle że w szwajcarskiej Bazylei, pierwsze, pośmiertne wydanie Poetices libri septem Juliusa Caesara Scaligera. Ta czasowa zbieżność jest, oczywiście, sprawą czystego przypadku. Nie wiemy, czy Kochanowski kiedykolwiek przestudiował to dzieło, ale na pewno nie mógł go znać w momencie, gdy układał hymn dołączony później do Zuzanny. Zaraz na początku, w rozdziale otwierającym pierwszą księgę dzieła, Scaliger dowodził wyższości poezji nad innymi pokrewnymi sztukami. Przewaga ta miała, jego zdaniem, wynikać przede wszystkim $z$ faktu, że o ile przedstawiciele tych ostatnich jedynie naśladują rzeczywistość, można ich zatem porównać do mimów albo aktorów, o tyle poeta zdolny jest sam tworzyć rzeczy nieistniejące, stając się w ten sposób niejako „drugim Bogiem”. Według Scaligera dobrze zdawali sobie z tego sprawę już starożytni greccy mędrcy, którzy znaczenie słowa „poeta” („poietēs”) wywodzili od „tworzyć” lub „robić” („pará tò poieīn”)

Mogłoby się zatem wydawać, że Scaliger przeciwstawia się tutaj dominującemu dotąd w myśli chrześcijańskiej poglądowi, który przed wiekami św. Augustyn zamknął w zwięzłej, często przez różnych późniejszych autorów przywoływanej formule: „Creatura non potest creare”. Sprawa jest jednak nieco bardziej skomplikowana, co znalazło swoje odzwierciedlenie już choćby w starożytnych przekładach początkowych fragmentów Księgi Rodzaju i w komentarzach do niej. W hebrajskiej Biblii termin „bara [tworzyć]” był rzeczywiście zarezerwowany tylko dla Boga7. Tłumacze Septuaginty, starając się go oddać, $z$ dość oczywistych względów nie chcieli w tym kontekście używać kojarzących się im chyba z platońską tradycją greckich czasowników „demiurgeīn” lub „poieīn”. Dlatego posłużyli się rzadszym i nieco bardziej wyszukanym czasownikiem „ktídzein [zakładać]”, wywodzącym się od rzeczownika „ktístēs”, pierwotnie oznaczającego właściwie założyciela miasta. Jego odpowiednikiem był odnoszony często do Boga przez pisarzy łacińskich termin „Conditor" (występujący np. na początku sławnego hymnu św. Ambrożego Aeterne rerum Conditor... $)^{8}$. Nie wszyscy jednak autorzy wczesnochrześcijańscy równie skrupulatnie i konsekwentnie trzymali się tych terminologicznych rozróżnień. Tak więc św. Atanazy w swojej obronie Symbolu nicejskiego pisał:

Bóg [...] tworzy i tworzenie (tò ktídzein) przypisuje się również człowiekowi [...]. Ale czy Bóg tworzy tak samo, jak czynią to ludzie? [...] Porzuć tę myśl: terminy te inaczej rozumiemy w odniesieniu do Boga,

6 J. C. S c a li ig e r, Poetices libri septem [...] ad Sylvium filium. Basileae 1561, s. 3: „Sola poesis haec omnia complexa est, tanto quam artes illae excellentius, quod ceterae (ut dicebamus) res ipsas, uti sunt, repraesentant, veluti aurium pictura quadam, at poeta et naturam alteram, et fortunas plures etiam; ac sese demum isthoc ipso perinde ac Deum alterum efficit. Nam quae omnium opifex condidit, eorum scientiae tamquam actores sunt, poetica vero quum et speciosius quae sunt, et quae non sunt, eorum speciem ponit; videtur sane res ipsas non ut alae, quasi histrio, narrare, sed velut alter Deus condere, unde cum eo commune nomen ipsi non a consensu hominum, sed a naturae providentia indutum videatur. Guod nomen Graeci sapientes ubi commodissime pará tò poieīn effinxissent [...]". Zob. M. M a c k, Sidney's Poetics: Imitating Creation. Washington, D.C., 2004, s. 84-86.

8 Formy „condere” oraz „condidit” w odniesieniu zarówno do Stwórcy, jak i do poety pojawiają się zreszta przecież także w przytoczonym tu w przypisie 6 fragmencie Poetyki S calige ra. 
a inaczej w odniesieniu do ludzi. Bóg bowiem tworzy tak, że powołuje nieistniejące do istnienia, nie potrzebując do tego celu niczego, człowiek natomiast pracuje w pewnym istniejacym już wcześniej materiale (hypokeiménē hýlē) ${ }^{9}$.

We fragmencie tym, mimo że ludzkie działania twórcze zostają bardzo wyraźnie odróżnione od Boskich, określono je jednak za pomocą czasownika zastrzeżonego zwykle dla tych drugich. Nie brakowało wszakże autorów postępujących odwrotnie. W łacińskiej wersji Recognitiones Klemensa Rzymskiego, jedynej, jaka dotrwała do naszych czasów, Bóg występuje jako „artifex” i „opifex”, którymi to terminami Cyceron, Seneka, Chalcydiusz i inni rzymscy pisarze oddawali zwykle Platońskie „demiurgós”. Repertuar tych określeń był zresztą szerszy, obejmował również słowa takie, jak ,fabricator”, „genitor”, „aedificator” czy wreszcie „architectus”. Wszystkie one będa powracały w dziełach łacińskich autorów chrześcijańskich, nawet jeśli skądinąd większość z nich w teorii odróżniała Boży modus operandi od poczynań Platońskiego demiurga, które jako jedyne mogły być w praktyce naśladowane przez ludzi ${ }^{10}$. Jego działania zmierzały w zasadzie tylko do przekształcenia chaotycznej i bezkształtnej pierwotnej materii (hýlē) w uporządkowany i racjonalny kosmos. Warto zauważyć przy okazji, że Scaliger najwyraźniej jego właśnie miał na myśli, nazywając poetę drugim Bogiem ${ }^{11}$, następna księga Poetyki nosiła bowiem tytuł Hýle i traktowała o języku jako materii, $\mathrm{z}$ której poeta kształtuje swoje dzieło, o metrum, rytmie, stopach, miarach wierszowych oraz strofach. Oczywiście, jeśli przyjmiemy tradycyjny, arystotelesowski punkt widzenia, zwłaszcza owe miary i strofy nie sa już właściwie materia poezji, lecz jej formą; te subtelne filozoficzne rozróżnienia nie będą nas jednak dalej zajmować, ponieważ nie poglądy Scaligera stanowia główny przedmiot podjętych tutaj rozważań. Warto wszakże również pamiętać, że tytuł owej drugiej księgi jego dzieła to tylko pewna metafora, język zaś jako taki jest przecież w gruncie rzeczy bytem par excellence „hylemorficznym”.

Poglądy Scaligera przedstawiłem tutaj zresztą nie dlatego, że dzieło jego wywarło jakiś bezpośredni wpływ na twórczość Kochanowskiego, nie mamy na to bowiem,

9 Cyt. za: M. C. N a h m, The Theological Background of the Theory of the Artist as Creator. „Journal of the History of Ideas" 8 (1947), nr 3, s. 364.

10 Sytuację komplikował zresztą dodatkowo fakt, iż w samej Biblii, konkretnie zaś w rozdziale 11 Księgi Madrości, najpierw czytamy o wszechmogącej ręce Boga, która „świat stworzyła z bezładnej materii” (w. 17), a nieco dalej dowiadujemy się o Stwórcy, że „wszystko urządził według miary i liczby, i wagi” (w. 20). Ksiegga ta została napisana po grecku najprawdopodobniej w Aleksandrii w II w. p.n.e. Można w niej znaleźć wiele podobnych śladów wpływu myśli greckiej, nic tedy dziwnego, że Żydzi, a później również protestanci nie zaliczali jej do kanonu Pisma, katolicy jednak uznawali ją za kanoniczną (czy może ściślej: deuterokanoniczną).

11 Jest to o tyle interesujące, że np. polemizując $z$ Cardanem w swoich ogłoszonych po raz pierwszy w Paryżu w r. 1557 Exotericae exercitationes J. C. S c alig er nie tylko bronił Arystotelesa przed zarzutem, iż Bóg jest dla niego raczej ,administratorem” wszechświata niż jego przyczyną sprawczą (causa efficiens), ale przy okazji zaatakował również współczesnych sobie renesansowych zwolenników neoplatonizmu, koronnym zaś argumentem, którym się w tym przypadku posłużył, aby wykazać podstawową sprzeczność między platonizmem a chrześcijaństwem, był właśnie fakt, iż w Timajosie ich starożytny mistrz przedstawił Boga jako rzemieślnika zręcznie przetwarzającego pierwotną materię, a nie jako Stwórcę powołującego do istnienia świat ex nihilo. Zob. K. Sa kam o t o, Creation, the Trinity and Prisca Theologia in Julius Caesar Scaliger. „Journal of the Warburg and Courtauld Institutes" 73 (2010). 
jako się rzekło, żadnych wyraźnych dowodów. Ważniejsze jest chyba coś innego: Poetyka wpisuje się w pewien szerszy kontekst dokonującej się w dobie renesansu radykalnej zmiany paradygmatu, o której nie tak dawno pisał Giuseppe Mazzotta w swojej książce łączącej trzy podstawowe zalety: mądrej, cechującej się pięknym stylem i krótkiej ${ }^{12}$. Książka ta, czy może raczej książeczka, to właściwie zbiór kilku studiów poświęconych różnym tekstom, poczynając od Baśni o Orfeuszu Poliziana, a kończąc na Burzy Szekspira, Nowej Atlantydzie Bacona i Don Kichocie Cervantesa. Głównym jej przedmiotem jest proces „wynajdywania”, a nie, jak chciał Burckhardt, „odkrywania” świata, a także sama idea tworzenia go za pomoca „utopii, magii, nauki, sztuki oraz teatru", wyobrażeniowych elementów, których wzmożone występowanie miało, zdaniem Mazzotty, charakteryzować właśnie ową fundamentalną zmianę paradygmatu odróżniającą renesans od epoki poprzedniej ${ }^{13}$. Nie zajmuje się w niej natomiast autor obszernymi poematami ułożonymi przez Du Bartasa i Tassa, których głównym tematem jest szczegółowy opis stworzenia świata przez Boga, chociaż pojawienie się tych dzieł pod koniec XVI w. odnotowuje przelotnie jako jeden $z$ wielu symptomów opisywanych przez siebie przemian ideowych i estetycznych. Zapowiada również przy okazji powstanie nowej ksiaż̇i im właśnie poświęconej. Jego wizja owych dokonujących się w renesansie transformacji została siłą rzeczy tylko szkicowo zarysowana, znajdujemy też w jej ramach trochę uproszczeń, które mogłyby bez wątpienia skłaniać do dyskusji. Taka dyskusja nie jest jednak tutaj do niczego potrzebna, dotyczyłaby bowiem wyłącznie pewnych szczegółowych, $\mathrm{z}$ naszego punktu widzenia niezbyt istotnych, kwestii. Wypada $z$ niej zatem po prostu zrezygnować.

Wspomniana wcześniej zasadnicza zmiana paradygmatu, do której doszło u progu epoki nowożytnej, polegać miała, zdaniem Mazzotty (który zresztą nie jest chyba w tym punkcie szczególnie oryginalny), głównie na stopniowym odejściu od dominującej dotąd postawy wobec świata. Dla ludzi średniowiecza był on przede wszystkim gigantyczną księgą spisaną przed wiekami digito Dei. Jej sens rozpoznawano wówczas głównie dzięki kontemplacji i stałemu konfrontowaniu uzyskanych w ten sposób wyników z przesłaniem drugiej wielkiej księgi - Biblii, która miała przecież tego samego Autora. Renesans natomiast wyrażał siebie nie poprzez kontemplację zastanej rzeczywistości, lecz raczej w działaniu, zwłaszcza zaś w rozmaitych aktach tworzenia. W przedmowie do swojej książki Mazzotta pisał:

Nowoczesny świat nie jest już dłużej, jak to było w wiekach średnich, księgą, która istniała przed nami i której znaki staramy się odcyfrować w świetle zasad wywiedzionych z biblijnej hermeneutyki. Nowoczesny świat [...] został stworzony przez ludzką sztukę i wolę. Może on być labiryntem albo zupełnie racjonalną naukową utopią nakreśloną przez Campanellę czy Bacona. Jest on jednak światem ludzkim, jego zaś emblematem jest dzieło sztuki ${ }^{14}$.

Kontemplacja jako taka oczywiście nie przestaje być dla wielu renesansowych autorów ważna, wiązałoby się to bowiem ostatecznie $\mathrm{z}$ zakwestionowaniem wartości nauk płynących z lektury dzieł różnych starożytnych filozofów, którzy, jak 
choćby Arystoteles w księdze X Etyki nikomachejskiej, zapewniali, że to właśnie kontemplacja jest dla ludzi jedynym źródłem prawdziwego szczęścia ${ }^{15}$. W teorii zatem vita activa nie zdobyła sobie żadnej wyraźnej przewagi nad życiem kontemplacyjnym. W praktyce, a więc w życiu społecznym, sprawy miały się zapewne inaczej, z punktu widzenia podjętych tutaj rozważań to jednak zagadnienie raczej drugorzędne ${ }^{16}$. Istotniejsze staje się coś innego. Dla wielu renesansowych twórców filozoficzna kontemplacja porządku świata nie jest już zwykle celem samym w sobie. Staje się ona raczej tylko pewnym punktem wyjścia dla ich dalszej twórczej aktywności. Człowiek renesansu to według Mazzotty przede wszystkim homo aestheticus, kontempluje on, podobnie jak przynajmniej niektórzy jego średniowieczni poprzednicy, piękno istniejącego świata, który jednak nie jest przecież doskonały, co prowokować może do podjęcia próby jego swoistej dekonstrukcji, a niekiedy wręcz do kreowania zupełnie nowych światów. W tej bardzo szczególnej sytuacji:

Utwór poetycki [...] jest symbolicznym locus, w którym światy rzeczywiste, możliwe i alternatywne zostały wyobrażone i pozwolono im na wzajemną konfrontację. Jest tu jednak również coś więcej. Poezja w renesansie rozumiana bywa na różne sposoby. Neoplatonicy i neoarystotelicy widzieli ją odmiennie: jako fantastyczną operację wyobraźni [...], ale także jako produkcję i naśladowanie. [...] Zawsze też, przynajmniej od czasów Dantego, poezja była rozumiana jako teren dialogu wszystkich sztuk [... ${ }^{17}$.

Ten dialog sztuk i nauk prowadzi w konsekwencji do systematycznego konfrontowania różnych punktów widzenia, rozmaitych tradycji filozoficznych i religijnych, które, jakby przeglądając się w sobie nawzajem i przenikając, dają w efekcie pewną encyklopedyczną zbitkę, której wyraźnie zaznaczające się i przybierające rozliczne formy istnienie stanowi, zdaniem Mazzotty, szczególną właściwość renesansowej praktyki literackiej.

Po tych, może nieco zbyt rozbudowanych, wstępnych uwagach powrócić wypada do - stanowiącego główny temat podjętych tutaj rozważan - problemu owej renesansowej cosmopoiesis uprawianej przez Kochanowskiego. Podstawową kwestią, którą spróbujemy rozstrzygnąć, jest pytanie, czy tworząc swój poetycki świat był on tylko kolejnym wcieleniem owego Platońskiego demiurga, występując jako typowy renesansowy poeta faber, czy też w swoich działaniach usiłował niekiedy również naśladować chrześcijańskiego Boga, którego moc była większa, a kompetencje bardziej rozległe. Odpowiedź na to pytanie jest o tyle trudna, że sam poeta w tych kwestiach właściwie się nie wypowiadał, skazani zatem jesteśmy jedynie na wnioski płynące $z$ analizy jego dzieł.

O tych zagadnieniach pisałem nieco szerzej w artykule Sub tegmine tiliae. Arkadyjskie „otia” Jana Kochanowskiego (w zb.: Staropolskie Arkadie. Red. J. Dąbkowska-Kujko, J. Kra uze- Ka r piń s ka. Warszawa 2010).

16 Jest zresztą sprawą wielce wątpliwą, czy kiedykolwiek w praktyce społecznej vita contemplativa zdobyła sobie jakąś przewagę nad konkurencyjnymi modelami życia. Dotyczy to również wieków średnich. Nie można zapominać, że piśmiennictwo tego okresu, stanowiące główne źródło naszej wiedzy na ten temat, było w przytłaczającej swojej większości dziełem duchownych i siłą rzeczy reprezentowało ich system wartości i oczekiwań.

Mazzotta, op. cit., s. XIV. 
Demiurgiczny aspekt owej twórczej aktywności Jana z Czarnolasu jest oczywisty. Demiurg Platona tylko przekształca pierwotny chaos w kosmos. To w gruncie rzeczy specyficzny demon porządku. Również Kochanowski, jak każdy poeta, nie tworzy ex nihilo - swój świat konstruuje ze słów, które w większości istniały przed nim, chociaż zdarza mu się z rzadka wprowadzać różne neologizmy, i one jednak najczęściej są wyłącznie kalkami lub spolszczeniami wyrazów pochodzących z innych języków ${ }^{18}$. Ta językowa „hýle”, jak ją określił w swojej Poetyce Scaliger, to materia prima poezji, którą dzisiaj nazywamy zwykle po prostu językiem naturalnym. Nie jest on, oczywiście, czystym, bezkształtnym chaosem, obowiązuje bowiem w jego ramach pewien pierwotny porządek, opisywana m.in. przez gramatykę wewnętrzna logika. Podstawowe zadanie każdego poety polega zatem na przekształceniu owego naturalnego języka w język artystyczny. Posługując się terminologią XX-wiecznej semiotyki można powiedzieć, że poeta konstruuje w tym celu pewien „wtórny system modelujacy”. W efekcie jego nałożenia na język naturalny powstaje właśnie język artystyczny, ten zaś, jak utrzymywał kiedyś Jurij Łotman, ,jest w swej istocie określonym modelem świata"19. Wolno zatem przyjąć, że podjęty przez Kochanowskiego trud stworzenia nowego polskiego języka artystycznego, dość wyraźnie odbiegającego od wcześniejszych podobnych konstrukcji, które poeta mógł łatwo znaleźć w twórczości swoich poprzedników (np. Marcina Bielskiego, ale zwłaszcza Mikołaja Reja), był prawdziwym punktem wyjścia całej jego literackiej cosmopoiesis. W oczach wielu współczesnych Kochanowskiemu czytelników ten aspekt jego poetyckiej aktywności przesądzał niewątpliwie o szczególnym miejscu, jakie zajął on wśród rodzimych twórców. Jan Januszowski w znanym wstępie do zbiorowej edycji jego dzieł, tłumacząc przyczyny, które spowodowały, że zgromadził je wszystkie w jednym tomie, pisał m.in.:

Po czwarte, abym dogodzić mógł częścią tym, którzy pragnęli, aby wszytki rzeczy jego na świat wydane były, częścią też tym, którzy by się radzi przypatrzyli i ozdobie rzeczy samej, i położeniu słów, jakim porządkiem iść by słusznie miały, w czym widzę, że nad wszytki insze przodkował barzo ${ }^{20}$.

Wypowiedź Januszowskiego brzmi dzisiaj, być może, trochę naiwnie, jednak sam fakt, iż XVI-wieczni czytelnicy chcieli się od Kochanowskiego uczyć przede wszystkim owego „położenia słów”, aby zrozumieć ,jakim porządkiem iść by słusznie miały", dobrze chyba świadczy o ich zdrowym rozsądku, ale także o umiejętności uchwycenia tego, co naprawdę istotne. Przywołany tutaj na wstępie Northrop Frye zauważył kiedyś nie bez racji, że poeci często nie są od innych ludzi ani mądrzejsi, ani głupsi - tym, co ich wyróżnia, jest właśnie umiejętność układania słów w odpowiednim porządku ${ }^{21}$. W jakiej mierze wspomniane „położenie słów” w dziełach czarnoleskiego poety stanowi produkt jego własnej inwencji, w jakiej zaś na-

Pamiętać zresztą należy, iż Kochanowski był przecież poetą dwujęzycznym. Jest wszakże rzeczą wielce charakterystyczną, że w swojej poezji unikał konsekwentnie makaronizaowania. Inaczej rzecz się miała z jego listami, w których, zgodnie $z$ humanistyczną modą, systematycznie przetykał polski tekst łacińskimi wstawkami. 
śladowania klasycznych i zachodnioeuropejskich wzorów, to kwestia osobna. W każdym razie wykreował on stopniowo pewien własny model artystycznego języka, stanowiący materię, z której dalej formował swoje poetyckie światy, nieustannie przy tym eksperymentując i wsłuchując się w reakcje odbiorców ${ }^{22}$, co sprawiało, że i sam język wciąż się zmieniał, dostosowując się do nowych zadań stawianych przed nim przez poetę. Kierunek tych przemian nie jest dzisiaj łatwy do uchwycenia m.in. dlatego, że chronologia twórczości Kochanowskiego nie da się w sposób precyzyjny i ostateczny ustalić. Pieśni i Fraszki np. pisał on przez wiele lat, ale w przypadku większości utworów znamy tylko ich ostateczny kształt, jaki przybrały w drukowanych edycjach z połowy lat osiemdziesiatych XVI wieku. W tym miejscu nie musimy jednak na szczęście wchodzić głębiej w te skomplikowane z samej swej istoty kwestie.

Cosmopoiesis w twórczości Kochanowskiego realizuje się zatem na różnych poziomach, poczynając od sposobu stylistycznej i wersyfikacyjnej organizacji wypowiedzi. Każdy pojedynczy utwór, nawet dwuwierszowa fraszka, staje się swoistym „mikrokosmosem”, jednolitą, uporządkowaną całością, reprezentująca pewną szerszą kategorię (w tym przypadku gatunek literacki). Dotyczy to, oczywiście, nie tylko Kochanowskiego, lecz właściwie każdego poety, chociaż nie wszyscy w równie świadomy sposób próbowali $z$ tych „mikroświatów” konstruować większe całości, imitując niejako przy okazji Boski akt stworzenia opisany w hymnie Czego chcesz od nas, Panie...

Układając swoje poetyckie zbiory autor Fraszek, Trenów czy Pieśni był ich „budowniczym”, czyli - jak sam mówił - „cieślą, który to mistrował”, a zatem demiurgiem-architektem, w przemyślny sposób łączącym ze sobą przygotowane wcześniej elementy. Kochanowski podzielał niewatpliwie charakterystyczną dla wielu renesansowych literatów fascynację architektura jako sztuką tworzenia pięknej i uporządkowanej harmonijnie przestrzeni ${ }^{23}$. Stąd też w jego twórczości od czasu do czasu pojawiają się „architektoniczne” metafory, wywodzące się zapewne z dobrze mu znanej starożytnej teorii retorycznej, w której ramach dość często powracała przypominana przez różnych autorów analogia między sztuką literackiej kompozycji a umiejętnością wznoszenia budowli ${ }^{24}$. Nawet $\mathrm{w}$ przywoływanym już tutaj liście do Zamojskiego, przyznając, iż Odprawa nie została napisana całkiem zgodnie z regułami, posłużył się Kochanowski łacińskim określeniem „ad amussim”,

22 Bardzo symptomatyczny jest pod tym względem znany fragment listu J. Ko chanow skiego do J. Zamojskiego poprzedzającego wydanie Odprawy posłów greckich (Oprac. T. U le wi c z. Wyd. 12, przejrz. i uzup. Wrocław 1974, s. 4. BN I 3): „Rzeczy też drugie nie wedla uszu naszych. Inter caetera trzy są chory, a trzeci jakoby greckim chorom przygania, bo oni już osobny characterem do tego mają: nie wiem, jako to w polskim języku brzmieć będzie. Ale w tym niech będzie arbitrium W.M., albo raczej we wszytkim".

23 Zob. m.in. P. Palm e, Ut architectura poesis. W zb.: Idea and Form: Studies in the History of Art. Ed. N. G. Sa nd bla d. Stockholm 1959. - G. G o e b e 1, Poeta Faber. Erdichtete Architektur in der italianischen, spanischen und französischen Literatur der Renaissance und des Barock. Heidelberg 1971. - D. Cowling, Building the Text: Architecture as Metaphor in Late Medieval and Early Modern France. Oxford 1998. - R. E r i k s e n, The Building in the Text: Alberti to Shakespeare and Milton. University Park, Penn., 2001.

24 Pisał o tym L. M. Griffin (The Edifice Metaphor in Rhetorical Theory. „Speech Monographs” 27 $\langle 1960\rangle)$. 
czyli dosłownie: 'według ciesielskiego sznurka'. We Fraszkach (I 87) zaś czytamy np.:

Najdziesz tu fraszkę dobrą, najdziesz złą i śrzednią, Nie wszytkoć mury wiodą materyją przednią.

$Z$ boków cegłę rumieńszą i kamień ciosany, W pośrzodek sztuki kładą i gruz brakowany ${ }^{25}$.

Wiersz otwierający ten utwór stanowi być może, jak to już wcześniej zauważano, nawiązanie do epigramatu Marcjalisa (I 16):

Sunt bona, sunt quaedam mediocria, sunt mala plura quae legis hie. aliter non fit, Avite, liber ${ }^{26}$.

Rzymski poeta poprzestał jednak na prostym stwierdzeniu faktu, że w jego zbiorze ów Avitus może znaleźć wiersze dobre, średnie i złe, których jest zresztą więcej, dodając tylko, iż było to nieuniknione. Kochanowski nie ogranicza się do tak banalnej w gruncie rzeczy konstatacji. W jej miejsce wprowadza rozbudowana metaforyczną konstrukcję, nawiązująca dość wyraźnie do wspomnianej tutaj wcześniej tradycji retorycznej. Mógł mieć przecież w pamięci np. krótki fragment Institutio oratoria Kwintyliana (VIII 63), w którym ten porównywał sytuację mówców do sytuacji ludzi wznoszących budowlę z nieobrobionych kamieni, by na koniec stwierdzić: „Nie możemy ociosać ani wypolerować naszych słów, żeby uczynić je bardziej pasującymi do siebie, musimy zatem wziąć je takie, jakie są, i wybrać dla nich odpowiednie położenie"27. Kwintylian mówił tylko o szyku wyrazów, Kochanowski pisał o kompozycji zbioru poetyckiego, zasada pozostaje jednak ta sama: właściwy porządek, a nie jakość lub forma materiału decydują o wszystkim.

Przytoczona fraszka Kochanowskigo jest, oczywiście, przejawem autorskiej kokieterii, bez wątpienia bowiem nie włączył on do swojego zbioru żadnego epigramatu, o którego niskiej wartości artystycznej byłby całkowicie przekonany. Wiemy, że dokonał pewnej selekcji, o czym świadczy choćby fakt, iż części fraszek w owym tomie nie opublikował, uczynić to miał dopiero po jego śmierci Januszowski. Przeprowadzając ten wybór poeta postępował niekiedy w sposób dość bezwzględny. Fraszki 82, 83 i 84 z Ksiag pierwszych to trzy dystychy wydobyte z cyklu Na XII tablic ludzkiego żywota, który w całości ukazał się dopiero w wydaniu Fragmentów z 1590 roku $^{28}$. Były więc one owym „gruzem brakowanym”, który trafił do Fraszek jako materiał pochodzacy z rozbiórki innej, zapewne dla autora mniej istotnej, budowli poetyckiej. W Pieśniach natomiast znajdujemy przecież (jako utwór 14

Oczywiście, trudno wykluczyć, iż utwory pojawiające się we Fraszkach to tylko zaczątek cyklu, który poeta ukończył dopiero później. Wydaje się jednak, że było raczej odwrotnie, czego starałem się dowieść w artykule Cursus aetatis. O cyklu „Na XII tablic ludzkiego żywota” Jana Kochanowskiego („Roczniki Humanistyczne” $56\langle 2008\rangle$, z. 1).

J. Ko cha now ski, Fraszki. Oprac. J. Pelc. Wyd. 3, przejrz. Wrocław 1998, s. 44. BN I 163.

$\mathrm{Na}$ to nawiązanie do Marcjalisa zwraca uwage Pelc w swoim komentarzu (w: jw.).

Kw in ty li a n, Institutionis oratoriae libri duodecim. Ed. F. O. M e is t e r. T. 2. Lipsiae 1887, s. 90: „differenda igitur quaedam et praesumenda, atque ut in structuris lapidum impolitorum, loco quo convenit quodque ponendum, non enim recidere ea nec polire possumus, quo coagmentata se magis convenit quodque ponendum, non enim recidere ea nec polire p. 
Ksiag wtórych) m.in. wydobytą z ogłoszonej drukiem kilka lat wcześniej Odprawy posłów greckich znaną pieśń chóru zaczynającą się od słów „Wy, którzy Pospolitą Rzeczą władacie”. Tutaj wszakże sytuacja jest chyba nieco bardziej skomplikowana. Nie wiemy, jak długo Kochanowski pracował nad kompozycją zbioru, którego wydania zresztą nie dożył. Jest całkiem prawdopodobne, że jakiś jego zarys i wstępna koncepcja istniały już w momencie, gdy wysyłał Zamojskiemu pospiesznie przepisany tekst Odprawy, do którego włączył pieśń ułożoną pierwotnie z zupełnie innym przeznaczeniem. Lecz są to kwestie, których prawdopodobnie nigdy nie uda się nam ostatecznie rozstrzygnąć. Niezależnie wszakże od tego, czy pieśń została napisana jako część Odprawy, czy trafiła do niej z czegoś, co później miało się stać zbiorem zatytułowanym Pieśni, jaki dzisiaj znamy, jedno wydaje się pewne: Kochanowski był literackim architektem swobodnie operującym zgromadzonym wcześniej materiałem. Ten sam element mógł się powtarzać, jeśli tylko dobrze wpisywał się w logikę nowej całości. Trzeba zresztą zauważyć, że poeta nie popadał pod tym względem w przesadę.

Na twórczość Kochanowskiego można chyba patrzeć w dwojaki sposób. Można ją czytać w porządku diachronicznym, śledząc jej rozwój, będący wynikiem pojawiania się kolejnych tekstów. Jakimś utrudnieniem jest fakt, że sama chronologia da się ustalić tylko do pewnego stopnia. Drugi sposób to próba odtworzenia ostatecznego kształtu, w jakim poeta postanowił zachować swój dorobek. Nie ulega wątpliwości, że pod koniec życia zdecydował się go uporządkować, nadając mu postać przeznaczona dla potomnych. $\mathrm{W}$ tej perspektywie chronologia powstania poszczególnych fraszek, pieśni lub łacińskich elegii schodzi na plan dalszy (chociaż, oczywiście, nie jest bez znaczenia, gdy przystępujemy do ich interpretacji). Problem polega jednak na tym, że Kochanowski zmarł nagle, pozostawiając Januszowskiemu zadanie opublikowania reszty swojej spuścizny. Nie wiemy zatem, w jakim stopniu edycja zbiorowa poezji, ogłoszona przez tego ostatniego rok po śmierci autora, odzwierciedlała jego intencje. Nie objęła ona zreszta przecież całej jego twórczości, nawet tych dzieł, które wcześniej ukazały się drukiem osobno. Brakuje w niej choćby Fraszek i Psatterza. Wydaje się wszakże pewne, że Kochanowski stworzył wizję kształtu, w jakim jego poetyckie dokonania będą w przyszłości przemawiać do czytelników. Niewątpliwie rozmawiał o tych sprawach z Januszowskim, którego późniejsze działania w jakiejś mierze, chociaż nie do końca, oddawały intencje poety. $Z$ braku stosownej dokumentacji skazani jesteśmy jednak w tej kwestii tylko na snucie rozmaitych domysłów. W każdym razie to właśnie przygotowywane pod koniec życia wydanie zbiorowe miało chyba stanowić zwieńczenie i podsumowanie owej cosmopoiesis czarnoleskiego poety, było owym horacjańskim monumentum, które zgodnie $\mathrm{z}$ jego wolą trwać powinno dalej w pamięci przyszłych pokoleń. Miało też być ono precyzyjnie uporządkowaną całością, gdzie poczesne miejsce zajmowałyby wyraźnie wyodrębnione jednogatunkowe zbiory, każdy z nich zaś stanowiłby efekt nie tylko kumulacji materiału poetyckiego, lecz również jego przemyślanej selekcji - osobny świat zorganizowany według pewnych ściśle określonych reguł. Zasady te były inne we Fraszkach, inne w Trenach, a jeszcze inne w Pieśniach. Psałterz pominiemy, ponieważ z oczywistych powodów jego kompozycją nie kierowała inwencja samego Kochanowskiego. 
Kosmogoniczny aspekt najwyraźniej występuje w konstrukcji Fraszek. Są one poetycką budowlą, co wynika choćby z przytoczonej tutaj wcześniej fraszki I 87, lecz budowlą bardzo szczególną, owym labiryntem o „ścieżkach mylnych”, pojawiajaccym się w utworze 29 Ksiag trzecich ${ }^{29}$. W centralnym punkcie tego labiryntu rośnie czarnoleska lipa, z którą wiąże się cały zespół symbolicznych sensów: wyznacza ona bowiem oś świata (axis mundi), jest drzewem kosmicznym, występującym w różnych archaicznych modelach kosmologicznych, ale jednocześnie tradycyjnym symbolem miłości i prokreacji, dla Kochanowskiego zaś również kreacji poetyckiej ${ }^{30}$. Właściwie można by nawet uznać lipę za swoistą inkarnację albo epifanię jego cosmopoiesis, znajduje się w samym centrum świata Fraszek, uosabiając siłę, która ten świat powołała do istnienia.

Niezwykle różnorodny materiał poetycki został przez autora uporządkowany w sposób, który dla czytelników nie był zapewne oczywisty. Nie będę go tutaj szczegółowo przedstawiać, gdyż uczyniłem to już wcześniej w innym miejscu ${ }^{31}$. W każdym razie topografia zbioru została ukształtowana $z$ użyciem dość skomplikowanego systemu numerologicznych konstrukcji, odwołujących się do pitagorejskiej i neoplatońskiej symboliki liczb, przede wszystkim jednak do izopsefii, czyli praktyki obliczania, za pomoca przyjętej uprzednio skali, liczbowej wartości poszczególnych słów. Przed XVI-wiecznym czytelnikiem stawało zadanie o tyle trudniejsze, że fraszki w ówczesnych wydaniach nie były przecież numerowane. W ten sposób wpisana w nie została pewna ukryta struktura, którą dostrzec mógł tylko bardzo specyficzny typ odbiorcy. Poeta zresztą bynajmniej nie zachęcał nikogo do podejmowania wysiłków zmierzających do jej odnalezienia i rozwikłania. Wręcz przeciwnie, we wspomnianej fraszce III 29 pisał:

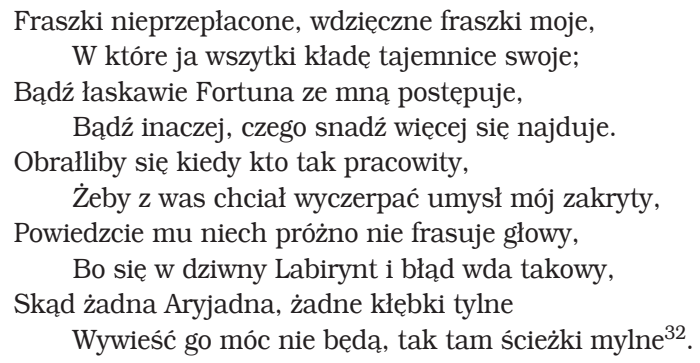

Nie wchodząc dalej w kwestie związane $z$ tym ukrytym porządkiem, który został przez poetę wpisany w kompozycję zbioru, warto zwrócić uwagę na to, iż twierdzi on wyraźnie, że we Fraszkach zawarł jakieś sekrety i że są to „tajemnice swoje”, autorów może przyjmować postać labiryntu albo np. racjonalnej utopii naukowej.

31 Zob. ibidem, rozdz. 1: Ordo in varietate. Pomysły te twórczo rozwiną J. K r o c z a k w oczekującym na druk artykule $W$ labiryncie. O układzie „Fraszek”. 
czyli że dotyczą one kwestii osobistych, a nie wielkich, kosmicznych problemów, zaprząających zwykle umysły uczonych i filozofów.

Zastanawiając się nad źródłem samego pomysłu, aby owe istotne osobiste treści ukrywać $\mathrm{w}$ tak skomplikowany sposób, $\mathrm{z}$ użyciem numerologicznych i izopseficznych spekulacji, wolno zapytać, co właściwie robił Kochanowski w kancelarii Zygmunta Augusta. Mało na ten temat wiemy. Jest dość prawdopodobne, że zajmował się korespondencją dyplomatyczną. Mógł zatem trudnić się np. nadawaniem oficjalnym listom monarchy lub kanclerza odpowiedniego kształtu stylistycznego. Oprócz jednak owej oficjalnej korespondencji z obcymi dworami lub z wysokimi urzędnikami państwowymi kancelaria wysyłała również listy adresowane do przebywających za granica dyplomatów. Ta korespondencja w XVI w. na terenie całej Europy zwykle nie była pisana „otwartym tekstem”, lecz kodowano ją w rozmaity sposób. Powstawały wtedy dość liczne traktaty poświęcone sztuce układania szyfrów ${ }^{33}$, zachowało się też do naszych czasów wiele przykładów zaszyfrowanych depesz dyplomatycznych. Stosowane przez poszczególne kancelarie szyfry nie były zreszta wbrew pozorom trudne do złamania. Dysponujemy dzisiaj np. depeszą sekretarza nuncjusza papieskiego dotyczącą różnych kwestii związanych z elekcją Henryka Walezego. Depesza ta została nawet opublikowana i odszyfrowana ${ }^{34}$. $\mathrm{Z}$ kręgu bliskich znajomych Kochanowskiego pochodzi list, w którym w kwietniu 1584 Stanisław Reszka donosił z Rzymu Janowi Zamojskiemu, że jeden $\mathrm{z}$ kardynałów wyraził zdziwienie faktem, iż oni obaj pisują do siebie po polsku lub po łacinie, „a cyfr żadnych nie używają”35. Czy Kochanowski sam parał się kodowaniem korespondencji dyplomatycznej dworu krakowskiego, oczywiście nie wiemy, ale jeśli nawet tego nie czynił, to $z$ pewnością dobrze wiedział o podobnych działaniach i znał ludzi, którzy w nich brali udział. Dodać jeszcze należy, iż w praktyce szyfrowania pewną rolę odgrywały niekiedy również książki. Podawane w listach zestawienia liczb odsyłały do stronic, wierszy i numerów słów w wierszach dzieła znanego zarówno nadawcy, jak i adresatowi.

Z punktu widzenia podjętych tutaj rozważań istotne jest jednak coś innego. Jako kreator poetyckiego świata Fraszek Jan z Czarnolasu zakodował w nim w wielce przemyślny sposób informacje na swój własny temat. W tym różni się od Platońskiego demiurga, któremu, jak wszystko wskazuje, nie przyświecały takie intencje. Zbliża go to natomiast w pewnym sensie do chrześcijańskiego Boga, który, zdaniem wielu teologów, tworząc świat, napisał jednocześnie ową księgę natury, umożliwiając dociekliwym umysłom poznanie Siebie, ponieważ, jak np. twierdzi w XII w. Hugo od św. Wiktora, „cała natura wyraża Boga” („Omnis natura Deum loquitur") $)^{36}$.

W księgozbiorze Zygmunta Augusta znajdowała się przynajmniej jedna tego rodzaju książka: Polygraphiae libri sex J. Trit h e mi u s a - zob. A. Kaw e c k a-G ry c z ow a, Biblioteka ostatniego Jagiellona. Pomnik kultury renesansowej. Wrocław 1988, s. 296 (nr katalogu 945).

34 Zob. A. C. Le ig h to n, A Papal Cipher and the Polish Election of 1573. „Jahrbücher für Geschichte Osteuropas" N.F., t. 17 (1969), z. 1.

35 Cyt. za: L. Ki e n i e w i c z, Łacina na dworze Stefana Batorego. W zb.: Listowne Polaków rozmowy. List tacińskojęzyczny jako dokument polskiej kultury XVI i XVII wieku. Red. J. Axer, J. Mańk ow s ki. Warszawa 1992, s. 98-99.

Hugo od św. Wiktora, Eruditio didascalica 6, 5 (PL 176, szp. 805). 
Od demiurga pojawiającego się w Timajosie żydowski i chrześcijański Bóg różni się jeszcze w inny sposób. Ten pierwszy tworzy wprawdzie świat, lecz później nie ingeruje już w jego dalsze losy ${ }^{37}$. Za zdarzające się od czasu do czasu kataklizmy odpowiedzialność ponosi wyłącznie natura. Nie są one jakaśs karą spadająca na stworzenia, lecz po prostu niebezpiecznymi zjawiskami. Bóg przeciwnie - co pewien czas dokonuje rozmaitych interwencji: zsyła potop (któremu $n b$. Kochanowski poświęcił przecież obszerną pieśń) lub sprawia, że morze rozstępuje się przed Izraelitami uciekającymi z Egiptu (wcześniej zaś sprowadza plagi na jego mieszkańców). Zawiesza zatem w razie potrzeby działanie praw natury, kierując się sobie jedynie znanymi powodami. Nie tylko stworzył świat ex nihilo, ale wciąż czuwa nad nim dokonując kolejnych cudów.

Kochanowski zbudował swój poetycki świat ze słów wyrażających pewien zespół poglądów i związany $z$ nim system wartości. Jego dzieło miało $z$ założenia trwać dłużej niż budowle wznoszone przez ludzi z kamienia i cegły. Żeby to jednak miało sens, sam poeta musiał wierzyć we własne przesłanie. Stąd też kryzys opisany w Trenach był nie tylko problemem Kochanowskiego jako człowieka, lecz może nawet bardziej Kochanowskiego jako twórcy. Weintraub w cytowanym już tutaj artykule uznał cykl za świadectwo głębokiego duchowego przełomu w życiu poety, który porzucić miał optymistyczną wizję świata dającą się zauważyć w hymnie Czego chcesz od nas, Panie... na rzecz jakiegoś, dziwnie zresztą definiowanego, „chrześcijańskiego pesymizmu”38. Dopatrywał się zatem Weintraub w Trenach początków nowej, barokowej postawy wobec świata i związanej z nią konceptystycznej poetyki. Wydaje się jednak, że tak jak hymn nie był żadnym „manifestem”, tak i Treny nie były aktem kapitulacji.

Żeby zaś zrozumieć, czym naprawdę były, warto podjąć próbę wpisania ich w ramy koncepcji owej renesansowej cosmopoiesis, stanowiącej główny przedmiot naszych dociekań. Konstruowany przez poetę gmach zaczął się chwiać pod wpływem zewnętrznych okoliczności. Gdyby jego twórca był tylko demiurgiem takim jak u Platona, pozostawiłby sprawy swojemu biegowi. Kochanowski jednak przyjmuje jakby rolę chrześcijańskiego Boga, czuwającego nad stworzonym przez siebie światem. Nie może wprawdzie dokonać cudu, nie wskrzesi córki, ale dzięki sile własnej poezji potrafi jej zagwarantować swoistą nieśmiertelność.

W tym celu zaaranżował w Trenach pewien magiczny rytuał. Aby zrozumieć, na czym on polegał, należy zacząć od dość naiwnego pytania: dlaczego cykl składa się z 19 utworów? Możliwa jest na nie bardzo prosta odpowiedź - tylu utworów potrzebował poeta, aby powiedzieć wszystko to, co zamierzał. Załóżmy jednak, że było inaczej. Już przy okazji omawiania konstrukcji Fraszek zauważyliśmy skłonność Kochanowskiego do numerologicznych spekulacji. Symboliczne znaczenie dziewiętnastki w dziełach dawnych autorów nie było przedmiotem szczególnie pogłębionej refleksji. Najwybitniejszy renesansowy numerolog, Pietro Bongo, w swoim dziele Numerorum mysteria, ogłoszonym po raz pierwszy w roku śmierci Kochanowskiego (a zatem $\mathrm{z}$ pewnością nie znanym poecie $\mathrm{w}$ czasach, kiedy pracował nad Trenami) twierdził np., że nie jest ona ani liczbą trójkątną, ani sześcienną, ani 
sferyczną, ani doskonałą, nie ma też w sobie żadnej „matematycznej elegancji”, i że - podobnie jak pozostałe liczby niezłożone - w Biblii odnosi się zwykle do grzechu i kary ${ }^{39}$. Dziewiętnastka jednak miała dla chrześcijan również inne symboliczne znaczenie, wynikające $z$ faktu, iż tyle właśnie lat liczył tzw. cykl Metona, za którego pomocą obliczano datę Wielkanocy. Dlatego też mogła symbolizować zmartwychwstanie lub po prostu życie wieczne. Jeśli Kochanowski chciał w swoim cyklu unieśmiertelnić Orszulkę, to taki wybór liczby składających się nań utworów mógł być z jego strony świadomym i przemyślanym posunięciem.

Mógł wszakże istnieć również inny powód. Przy całej swej opisanej przez Bonga niedoskonałości dziewiętnastka miała jedna zaletę: była liczbą nieparzystą, a w związku $z$ tym w zbiorze dawało się ustalić jego geometryczne centrum. Już pisząc o miejscu zajmowanym przez lipę w centralnym punkcie labiryntu Fraszek, wspominałem, że w miejscu tym ogniskuje się pewna szczególna moc. W Trenach środkowym tekstem jest dziesiąty utwór cyklu. W systemie symboliki pitagorejskiej dziesiątka stanowiła liczbę szczególną, określano ją mianem tetraktys, ponieważ powstawała w wyniku zsumowania ze soba pierwszych czterech liczb. To sprawiało, że przypisywano jej również wyjątkową magiczną siłę. Tren $X$ zaczyna się, jak wiadomo, od długiej serii pytań dotyczących miejsca pobytu zmarłej córki, układających się w katalog eschatologicznych wyobrażeń wywodzących się z różnych systemów religijnych. Po tym rozbudowanym wstępie czytamy:

Gdzieśkolwiek jest, jeśliś jest, lituj mej żałości.

A nie możesz li w onej dawnej swej całości,

Pociesz mię, jako możesz, a staw sie przede mną

Lubo snem, lubo cieniem, lub marą nikczemną ${ }^{40}$.

Nie jest to tylko niewinna poetycka apostrofa, lecz misternie skonstruowane nekromantyczne zaklęcie. Dodajmy - zaklęcie skuteczne, Orszulka bowiem rzeczywiście pojawia się przecież w ostatnim utworze zbioru. Czy nam się to podoba, czy też nie, autor Trenów występuje tutaj w roli renesansowego maga. Przy okazji znajdujemy w tym fragmencie odpowiedź na pytanie, dlaczego Tren XIX oprócz numeru został przez poetę opatrzony również tytułem. W swojej twórczości Kochanowski bardzo konsekwentnie trzymał się zasady, że albo nadawał poszczególnym utworom swoich zbiorów tytuły (jak we Fraszkach), albo numerował je (jak w Pieśniach). W Trenie XIX dodatkowy tytuł występuje tylko dlatego, że poeta stara się tutaj wyraźnie podkreślić, iż Orszulka stawiła się przed nim we śnie, nie zaś jako „cień” lub owa „mara nikczemna”. Można jeszcze dodać, że był to sen pojawiający się nad ranem, a tego rodzaju widzeniom zwykle przypisywano wówczas wyjątkową, niekiedy wręcz profetyczną funkcję.

Przy okazji warto też może zauważyć, iż między liczbami 10 a 19 dla lepiej wykształconych czytelników Kochanowskiego istniał pewien szczególny, dla nas

P. B on go, Numerorum mysteria. Lutetiae Parisiorum 1618, s. 423: „Numerus novenarius supra denarium neque trigonus est, neque cubicus, neque sphaericus, neque perfectus, nec denique ullam aliquam habet mathematicam elegantiam, sed cum sit primus incompositus ipse etiam, sicut et ceteri huius generis numeri, vitiis et castigationi addictus est". 
trudno dostrzegalny związek. Pitagorejczykom przypisywano kilka arytmetycznych odkryć, które dziś mogą się wydawać banalne. Mieli oni m.in. zauważyć, że sumy kolejnych liczb nieparzystych sa zawsze liczbami kwadratowymi: $1+3=4,1+3$ $+5=9,1+3+5+7=16$ itd. Suma liczb nieparzystych od 1 do 19 daje 100, jest zatem dziesiątką do kwadratu. Tak więc zaklęcie pada w dziesiątym utworze zbioru, jego efekt pojawia się zaś w tekście, którego numer kryje w sobie dziesiątkę podniesioną do drugiej potęgi.

Można w tym miejscu zapytać o cel, jaki przyświecał Kochanowskiemu, kiedy konstruował swój cykl w ten wielce szczególny sposób. Dla Weintrauba Treny były w twórczości poety zbiorem przełomowym, wyznaczającym moment porzucenia pewnej optymistycznej wizji świata, którą znajdujemy w jego wcześniejszych utworach. Tren XIX jest, zdaniem badacza, „słabszy od innych” i w gruncie rzeczy stanowi zbiór włożonych w usta matki argumentów o dość wątpliwej wartości. XX-wieczny literaturoznawca miał, oczywiście, prawo do wypowiadania ocen zgodnych z duchem czasów, w których pisał, i z jego własnymi przekonaniami. Nie jesteśmy wszakże zmuszeni iść jego śladem. Jeśli hymn Czego chcesz od nas, Panie... i Treny są manifestacjami pewnego światopoglądu, to stanowi to tylko jeden ich aspekt, i to chyba nie najistotniejszy. Sa to przede wszystkim wypowiedzi o charakterze artystycznym, w których ważniejsza od wiedzy okazuje się wyobraźnia. Innymi słowy, jako kosmopoietēs Kochanowski przedstawia świat po części takim, jaki jest, ale przede wszystkim takim, jaki chce, żeby był, jest bowiem świat - jak o tym pisał cytowany tutaj wcześniej Mazzotta - „stworzony przez ludzką sztukę i wolę”. Treny pojawiły się w twórczości poety w momencie, gdy osobista tragedia wstrząsnęła fundamentami wznoszonej przez niego poetyckiej budowli. Opisany w nich dość szczególny nekromantyczny rytuał miał chyba doprowadzić do jej magicznej reintegracji. Aby mogła się ona dokonać, Tren XIX musiał się w zakończeniu cyklu pojawić i nie stanowił on, wbrew temu, co twierdził Weintraub, żadnego manifestu chrześcijańskiego pesymizmu. Kochanowski może nie był, co mu niekiedy później zarzucano, dobrym katolikiem, był jednak z całą pewnością człowiekiem głęboko religijnym, do którego argumenty wygłaszane tutaj przez matkę z pewnościa przemawiały. Sam je zresztą przecież włożył w jej usta.

Konstruując swój poetycki kosmos Kochanowski przewyższał przywoływanego tutaj aż do znudzenia Platońskiego demiurga jeszcze pod jednym względem. Ten ostatni był genialnym rzemieślnikiem, zdolnym stworzyć niemal wszystko. Wydaje się wszakże, iż nie potrafił stworzyć samego siebie. Nie będziemy tutaj, oczywiście, wchodzić w rozważania, czy chrześcijański wieczny i wszechmogący Bóg byłby to w stanie uczynić, jest to bowiem jedynie wariant słynnego paradoksu omnipotencji, podjęcie zatem takich rozważań skazywałoby nas z góry na spektakularną klęskę. Jan z Czarnolasu jednak jako poeta nie tylko w pewnym sensie był do tego zdolny, ale po prostu tego dokonał. Świadomie i konsekwentnie wykreował swoje autorskie „ja”, a miejscem, w którym w syntetyczny sposób opisał etapy owego procesu, była otwierająca Księgi trzecie fraszka Do gór i lasów.

Pozornie tylko jest to bardzo zwięzła autobiografia, napisana z perspektywy kogoś, kto, po odbyciu długiej peregrinatio vitae, na starość powrócił ostatecznie w rodzinne strony. Znajdujemy w niej katalogowe wyliczenie odwiedzonych krajów, 
a następnie pełnionych w życiu rozmaitych funkcji. $Z$ naszego punktu widzenia najbardziej interesująca jest jednak pojawiająca się dalej rekapitulacja:

Taki był Proteus, mieniąc się to w smoka,

To w deszcz, to w ogień, to w barwę obłoka.

Dalej co będzie? Śrebrne w głowie nici,

A ja $\mathrm{z}$ tym trzymam, kto co w czas uchwyci ${ }^{41}$.

Proteusz (czy jak chciał Kochanowski - Proteus) to jeszcze jedna mitologiczna figura, do której poeta porównywał samego siebie. Postać morskiego starca zajmowała zreszta poczesne miejsce w wyobraźni ludzi epoki renesansu ${ }^{42}$. Był on przede wszystkim symbolem ludzkiej zdolności do przystosowania się i autokreacji. Przedstawia go jako takiego Pico della Mirandola w słynnym fragmencie De hominis dignitate ${ }^{43}$, później zaś w podobnej roli powracać będzie w dziełach różnych autorów renesansowych. Kochanowski zatem pozornie tylko przywołuje mitologiczna postać dobrze zadomowioną w humanistycznej tradycji. Ciekawsze jest jednak to, co pisze we fraszce o samych niezwykłych przemianach morskiego bożka.

W swoim czasie Krzysztof Mrowcewicz słusznie zauważył, że ich zaproponowane przez Kochanowskiego zestawienie odwołuje się do tradycyjnego porządku czterech żywiołów ${ }^{44}$. Smok uchodził najczęściej za symbol chtoniczny, deszcz i ogień nie wymagaja oczywiście dodatkowego komentarza, „barwa obłoka” zaś wiąże się niewątpliwie $z$ powietrzem. Ten pomysł interpretacyjny można po prostu przyjąć, ale tylko jako pewien punkt wyjścia, otwierający drogę do dalszych rozważań. Warto się bowiem zastanowić nad symbolicznym sensem samego Proteusza, wykraczając poza krąg tradycyjnych odczytań jego postaci pojawiających się zwykle w pismach humanistów. Morski bożek odgrywał przecież dość istotną rolę również w systemie symboliki alchemicznej, gdzie oznaczał on przeważnie Merkuriusza, pierwszą materię, ale też aktywny, ulotny duchowy pierwiastek w ramach alchemicznego opus, przyjmujący kolejno rozmaite postacie ${ }^{45}$. Owo alchemiczne „dzieło” bywało opisywane przez poszczególnych autorów w różny sposób, najczęściej wszakże składało się z czterech podstawowych, następujących po sobie faz, z któ-

41 Kochanows ki, Fraszki, s. 115.

42 Zob. m.in. A. B. Gi a m at ti, Proteus Unbound: Some Versions of the Sea God in the Renaissance. W zb.: The Disciplines of Criticism: Essays in Literary Theory, Interpretation and History. Ed. P. Demetz, Th. Greene, L. Nels on Jr. New Haven, Conn., 1968. - B. Tha on, Spenser's Neptune, Nereus and Proteus: Renaissance Mythography Made Verse. W zb.: Acta Conventus Neo-Latini Bononiensis. Proceedings of the Fourth International Congress of Neo-Latin Studies. Bologna, 26 August to 1 September 1979. Ed. R. J. Sc hoe ck. Binghampton, N.Y., 1986. - M. J e a n n eret, Portrait of the Humanist as Proteus. „Diogenes” t. 44 (1996). - P. P e s i c, Shapes of Proteus in Renaissance Art. „Huntigton Library Quarterly” t. 73 (2010), nr 1. G. Pic o della Mirandola, Oratio de hominis dignitate. / Mowa o godności człowieka. Przekł., oprac. Z. Nerczuk, M. Olszews ki. Wstęp D. F a c ca. Warszawa 2010, s. 41. i lasów". W zb.: Przełom wieków XVI i XVII w literaturze i kulturze polskiej. Red. B. O tw i n o w s k a, J. Pelc. Wrocław 1984.

45 Zob. L. A b r a h a m, A Dictionary of Alchemical Imagery. Cambridge 1998, s. 158. 
rych pierwszą było nigredo (czerń), symbolizowane zwykle, chociaż nie tylko, przez chtonicznego smoka. Drugie stadium nazywane bywa ogonem pawia (cauda pavonis). Paw obrazuje tęczę, która ukazywać się miała w alembiku w czasie obmywania czarnego kamienia, czyli pierwotnej materii. Doprowadza ono kamień do fazy białości (albedo), wiązanej przez niektórych autorów z tzw. woda życia (aqua vitae). I wreszcie za sprawą ognia kamień osiaga ostatnią fazę swojej transformacji, zwaną najczęściej czerwienią (rubedo).

Proteus-Merkurius we fraszce Kochanowskiego przechodzi kolejno przez wszystkie te fazy, chociaż zapewne ze względów wersyfikacyjnych ich kolejność została nieco zaburzona. Owa cauda pavonis, czyli tęcza, pojawia się bowiem tutaj na końcu serii jako „barwa obłoka”. Proces formowania siebie przedstawia zatem poeta jako sekwencję alchemicznych transformacji, metaforę tę należy jednak chyba traktować dość poważnie $z$ uwagi na fakt, iż sama alchemia była rozumiana przez wielu jej adeptów nie tylko jako technika przekształcania metali w złoto, lecz również jako opis doniosłego duchowego procesu.

Nakładając ten rozbudowany alchemiczny schemat na ukazaną wcześniej w wierszu życiową drogę autora, możemy zauważyć pewne istotne zbieżności. Przede wszystkim dotyczą one punktu wyjścia i punktu dojścia. Punktem początkowym są owe wspomniane na początku „góry i lasy”, czyli rodzinne strony poety. Kochanowski dość często podkreślał swoje „leśne” pochodzenie. We fraszce Do poetów (III 14), porównując siebie do dobrego centaura Chirona, pisze więc: „i ja mieszkam w lesie"; wcześniej, przybywając na dwór Zygmunta Augusta, przyjmuje mitologiczną maskę Satyra, który też został przecież w dedykacji nazwany „leśną potwora”. Posiadłość Kochanowskiego ma las w samej swojej nazwie. W dodatku jest to czarny las. Poeta z pewnością wiedział, że po grecku las to „hýlē” i że słowo to oznaczało również materię. Czarnolas zatem po grecku nazywałby się „mélaina hýlē”. Tak więc miejsce, z którego Kochanowski pochodził, już w swojej nazwie zawierało wszystko to, co pozwalało kojarzyć je z owym alchemicznym nigredo, czyli ciemna, pierwotną materią. Na końcu życiowej drogi pojawiają się „śrebrne w głowie nici”. Ten fragment można potraktować chyba jako przejaw pewnej autoironii. Zamiast złota czy kamienia filozoficznego, których uzyskanie wieńczyć miało alchemiczne opus, widzimy tylko siwe włosy, zapowiadające nadejście starości. Zamykające fraszkę stwierdzenie: „A ja z tym trzymam, kto co w czas uchwyci”, ma zatem przede wszystkim oczywisty epikurejski wydźwięk, może być jednak również odczytywane w nieco inny sposób - jako skierowana do czytelnika instrukcja interpretacyjna: autor fraszek sam się ustawicznie zmieniał, a sens jego twórczości nie jest w związku z tym dla każdego łatwo uchwytny. To by chyba mogło zresztą tłumaczyć, dlaczego Kochanowski wciąż jest dla nas takim trudnym poetą.

Fraszka Do gór i lasów stanowi zatem modelowy opis autokreacji (można by powiedzieć: autopoiesis), objaśnionym za pomoca alchemicznej metafory. Warto przy okazji zauważyć, że cały zbiór Kochanowskiego dałoby się odczytywać w świetle symboliki alchemicznej. Często występującym tu symbolem alchemicznego opus jest np. labirynt, a i czarnoleska lipa mogłaby zostać uznana za owo Drzewo Filozoficzne, powracajace ustawicznie w pracach adeptów tej sztuki, która w czasach Kochanowskiego cieszyła się, przynajmniej w pewnych kręgach, dużym prestiżem (interesowali się nią również niektórzy jego znajomi, jak np. Olbracht Łaski). Pro- 


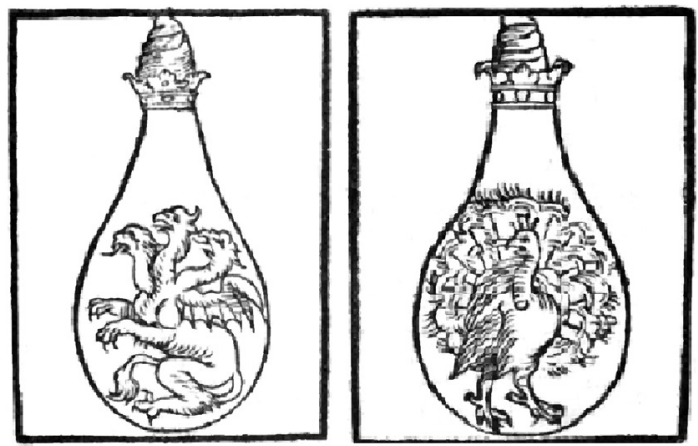

Nigredo, symbolizowane przez smoka, oraz cauda pavonis - drzeworyty w alchemicznym traktacie Salomona Trismosina Aureum vellus [...] (Rorschach 1598-1599)

blem polega jednak na tym, że alchemicy „przywłaszczyli sobie” cały zespół tradycyjnych symboli mitologicznych, przypisując im nowe specyficzne znaczenia. Kiedy pojawiają się one później w dziełach XVI-wiecznych literatów, trudno zwykle stwierdzić, czy rzeczywiście traktowali je oni jako symbole alchemiczne. W przypadku twórczości czarnoleskiego poety mamy do czynienia $\mathrm{z}$ taką właśnie rodzącą wiele wątpliwości sytuacją.

\section{Abstract \\ JACEK SOKOLSKI University of Wrocław \\ JAN KOCHANOWSKI'S COSMOPOIESIS}

Constructing his poetic world, Jan Kochanowski on the one hand acted as a typical Renaissance poeta faber pertaining to the figure of the demiurge from Plato's Timaeus, while on the other hand he transgressed thus established frames. He ordered collections of his poems as architectural compositions referring to the tradition preserved in old textbooks in rhetoric, yet filled them with deeply hidden pieces of information about himself, in which, as a matter of fact, he followed the Christian God's modus operandi. In doing so, he oftentimes took advantage of cryptological procedures used in the then diplomatic correspondence. The moment the world of words and values constructed in this way collapsed due to the poet's personal experience, in Treny (Laments) he brought about its magic reintegration. Kochanowski also surpassed Plato's demiurge in one more aspect. In his literary creativity he realised a peculiar act of auto-creation of which the description, employing alchemist symbolism, is found in the trifle Do gór i lasów (To the Mountains and Forests) (III 1). 